Research Article: Education

\title{
Perspektif Guru Terhadap Kemahiran Berfikir Aras Tinggi dalam Kalangan Pelajar
}

Nurulhuda Md Hassan', Nur An Nisa Fithri Mohd Noor ${ }^{1}$, Yamuna Thasarathan', Qarihatun Najah Zainudin ${ }^{2}$, Nur Syaidatul Aisyah Zainuri ${ }^{1}$, Nurul Raihana Najwa Mohamad Rizuaden ${ }^{2}$, Nurfara Adilah Muhamad Fauzi ${ }^{2}$, Nurfatihah Tumin ${ }^{2}$, Nur Afina Syahida Mohamad Jefri ${ }^{3}$

${ }^{1}$ Fakulti Pembangunan Manusia, Universiti Pendidikan Sultan Idris. Perak, Malaysia.

${ }^{2}$ Fakulti Sains dan Matematik, Universiti Pendidikan Sultan Idris. Perak, Malaysia.

${ }^{3}$ Fakulti Fakulti Bahasa dan Komunikasi, Universiti Pendidikan Sultan Idris. Perak, Malaysia.

Article History

Received:

15.07.2021

Revised:

27.07.2021

Accepted:

09.08.2021

*Corresponding Author: Nurulhuda Md. Hassan

Email:

nurulhuda.mh@fpm.upsi.edu.my

This is an open access article, licensed under: $\mathrm{CC}-\mathrm{BY}-\mathrm{SA}$
Abstrak: Kajian ini dijalankan bagi meneroka perspektif guru berkaitan kemahiran berfikir aras tinggi (KBAT) dalam kalangan pelajar. Kajian ini menggunakan kaedah temubual separa berstruktur yang melibatkan seorang guru yang berpengalaman. Instrumen yang digunakan dalam kajian ini terdiri daripada protocol temubual dan komputer riba. Hasil kajian mendapati bahawa KBAT dalam kalangan pelajar masih perlu diperkasakan dan dipengaruhi oleh perbezaan tahap sosioekonomi dan jenis sekolah. Faktor pelajar, alat bantu mengajar, dan keadaan bilik darjah didapati mempengaruhi pemilihan strategi pengajaran bagi memupuk KBAT dalam kalangan pelajar. Hasil kajian turut mendapati bahawa teknik menyoal boleh digunakan bagi meningkatkan KBAT dalam kalangan pelajar, manakala pemberian soalan KBAT secara konsisten, penggunaan kaedah pembelajaran abad ke-21 (PAK21) dan pemberian tugasan berkumpulan boleh digunakan untuk menggalakkan aplikasi KBAT ketika pelajar menghadapi penilaian. Dapatan kajian turut menunjukkan bahawa kekangan masa dan faktor pelajar yang tidak aktif memberikan cabaran kepada guru untuk memupuk KBAT dalam kalangan pelajar. Sebagai implikasi, semua pihak perlu memainkan peranan yang sewajarnya dalam usaha meningkatkan KBAT dalam kalangan pelajar agar matlamat pendidikan dapat direalisasikan.

Kata Kunci: Kemahiran Berfikir Aras Tinggi, Pembelajaran Abad Ke-21, Teknologi Maklumat dan Komunikasi.

Teachers' Perspectives on Higher Order Thinking Skills Among Students

Abstract: This study was conducted to explore the perspectives of teachers related to high -level thinking skills (HLTS) among students. This study used a semi -structured interview method involving an experienced teacher. The instruments used in this study consisted of an interview protocol and a laptop. The results of the study found that HOTS among students still need to be empowered and influenced by differences in socioeconomic levels and types of schools. Student factors, teaching aids, and classroom conditions were found to influence the selection of teaching strategies to foster HOTS among students. The study also found that questioning techniques can be used to improve KBAT among students, while giving KBAT questions consistently, the use of 21st century learning methods (PAK21) and group assignments can be used to encourage the application of KBAT when students face assessment. The findings of the study also show that time constraints and inactive student factors provide a challenge to teachers to cultivate HOTS among students. As an implication, all parties need to play an appropriate role in efforts to improve HOTS among students so that educational goals can be realized.

Keywords: High-Order Thinking Skills, 21st Century Learning, Information and Communication Technology. 
Nurulhuda Md Hassan, Nur An Nisa Fithri Mohd Noor, Yamuna Thasarathan, Qarihatun Najah Zainudin, Nur Syaidatul Aisyah Zainuri, Nurul Raihana Najwa Mohamad Rizuaden, Nurfara Adilah Muhamad Fauzi, Nurfatihah Tumin, Nur Afina Syahida Mohamad Jefri.

Perspektif Guru Terhadap Kemahiran Berfikir Aras Tinggi dalam Kalangan Pelajar.

Journal of Humanities and Social Sciences, vol. 3, no. 2, pp. 50-56, August 2021. DOI: 10.36079/lamintang.jhass-0302.237

\section{Pengenalan}

Kemahiran berfikir aras tinggi (KBAT) merujuk kepada tiga kemahiran yang berada pada aras keempat, kelima, dan keenam dalam Taksonomi Bloom, iaitu analisis, sintesis, dan penilaian [1]. Selain itu, KBAT juga merujuk kepada kebolehan seseorang untuk mengaplikasi pengetahuan, kemahiran dan nilai dalam penaakulan, refleksi, penyelesaian masalah, membuat keputusan, berinovasi dan mencipta sesuatu yang baru [2].

Menurut Karim \& Puteh [3], KBAT merupakan antara aspek penting yang perlu diberi perhatian dalam konteks pengajaran dan pembelajaran. Ini adalah kerana, KBAT membolehkan seseorang pelajar untuk mengaplikasi kemahiran berfikir secara kritis, logik, reflektif, dan kreatif [4]. Di samping itu, KBAT juga membolehkan pelajar untuk menjadi lebih imaginatif, inovatif, dan kreatif [5]. Selain itu, KBAT juga membolehkan menganalisis, menilai, dan membuat inovasi dalam menyelesaikan masalah-masalah yang berlaku dalam kehidupan sebenar [6].

Di Malaysia, Pelan Pembangunan Pendidikan Malaysia 2013-2025 [14] menggariskan pelbagai strategi yang telah dirancang oleh kerajaan dalam tempoh 13 tahun bagi meningkatkan kualiti pendidikan di Malaysia, seterusnya memastikan kejayaan Malaysia dalam menghadapi cabarancabaran yang wujud dalam abad ke-21 [3]. Hal ini adalah bertepatan dengan prinsip pembelajaran abad ke-21 (PAK21) yang mengkehendaki pelajar untuk memiliki KBAT [6]. KBAT dalam kalangan pelajar merupakan antara aspek yang diberikan perhatian dalam aspirasi murid seperti yang dinyatakan dalam PPPM 2013-2025. Bagi mencapai aspirasi tersebut, pelbagai transformasi telah dilakukan, termasuklah pelaksanaan Kurikulum Standard Sekolah Rendah (KSSR) bagi menggantikan Kurikulum Bersepadu Sekolah Rendah (KBSM) pada tahun 2011 [3]. Selain itu, semakan terhadap soalan-soalan yang terkandung dalam penilaian juga telah dilakukan bagi memastikan soalan-soalan tersebut menggalakkan pelajar untuk mengaplikasi KBAT.

Guru memainkan peranan penting dalam memastikan aspirasi murid seperti yang dinyatakan dalam PPPM 2013-2025 dapat direalisasikan. Ini adalah kerana, selain menjadi tulang belakang kepada system pendidikan, mereka juga merupakan pemula kepada dasar-dasar dan matlamatmatlamat yang ditetapkan oleh kerajaan melalui Kementerian Pendidikan Malaysia [7]. Justeru, dalam konteks PAK21, guru dipertanggungjawabkan untuk memastikan elemen KBAT diterapkan bagi menggalakkan aktiviti-aktiviti berfikir secara mendalam dalam kalangan pelajar [8]. Menurut Othman \& Rahman [9], keberkesanan pembelajaran dipengaruhi oleh tahap penerapan elemen KBAt dalam proses pengajaran dan pembelajaran.

Guru boleh mengambil pelbagai inisiatif bagi menjayakan PPPM 2013-2025. Sebagai contoh, mereka digalakkan untuk mengaplikasi strategi-strategi pengajaran berpusatkan pelajar seperti yang disarankan dalam PAK21 yang merangkumi pembelajaran berasaskan projek dan pembelajaran kolaboratif serta pentaksiran autentik. Selain itu, mereka juga boleh mengaplikasikan pelbagai strategi yang boleh menggalakkan KBAT dalam kalangan pelajar. Antara strategi yang dimaksudkan termasuklah teknik menyoal, aktiviti penyelesaian masalah, pembelajaran berasaskan projek, penggunaan alat-alat pemikiran, simulasi, perbincangan, dan main peranan [8].

Menurut Chalkiadaki [10] dan Saputri et al. [11], dalam PAK 21, pembelajaran tidak lagi tertumpu kepada hafalan terhadap konsep-konsep yang dipelajari, tetapi turut melibatkan kemahiran untuk menganalisis permasalahan yang berlaku dalam kehidupan sebenar. Walaubagaimanapun, tinjauan literatur mendapati bahawa guru kurang bersedia untuk melaksanakan KBAT dalam kalangan pelajar [12]. Guru juga didapati berdepan dengan kekeliruan sama ada KBAT perlu diajar secara berasingan atau diintegrasikan dalam pengajaran harian [7]. Selain itu, mereka juga didapati kurang kreatif dari segi perancangan dan pelaksanaan KBAT dalam proses pengajaran dan pembelajaran [13].

Kajian ini dijalankan bagi meneroka perspektif guru berkaitan dengan KBAt dalam kalangan pelajar. Secara spesifik, objektif kajian ini adalah untuk meneroka perspektif guru berkaitan dengan:

1. Tahap KBAT dalam kalangan pelajar.

2. Faktor yang mempengaruhi guru dalam memilih strategi pengajaran bagi memupuk KBAT dalam kalangan pelajar.

3. Langkah untuk meningkatkan KBAT dalam kalangan pelajar.

4. Strategi untuk menggalakkan pelajar mengaplikasikan KBAT ketika menghadapi penilaian.

5. Cabaran guru untuk memupuk KBAT dalam kalangan pelajar.

6. Kesan sekiranya pelajar tidak memiliki KBAT. 
Nurulhuda Md Hassan, Nur An Nisa Fithri Mohd Noor, Yamuna Thasarathan, Qarihatun Najah Zainudin, Nur Syaidatul Aisyah Zainuri, Nurul Raihana Najwa Mohamad Rizuaden, Nurfara Adilah Muhamad Fauzi, Nurfatihah Tumin, Nur Afina Syahida Mohamad Jefri.

Perspektif Guru Terhadap Kemahiran Berfikir Aras Tinggi dalam Kalangan Pelajar.

Journal of Humanities and Social Sciences, vol. 3, no. 2, pp. 50-56, August 2021. DOI: 10.36079/lamintang.jhass-0302.237

\section{Metodologi Kajian}

Kajian ini menggunakan kaedah temubual yang melibatkan seorang guru yang berpengalaman. Temubual telah dijalankan melalui aplikasi Google Meet dan telah berlangsung selama 45 minit. Instrumen kajian terdiri daripada protokol temubual yang terdiri daripada soalan-soalan berkaitan KBAT dan komputer riba bagi merakam sesi temubual yang dijalankan. Beberapa langkah telah diambil sebelum temubual dijalankan seperti penyediaan soalan protokol temubual, pemilihan informan, dan penentuan masa dan tarikh untuk menjalankan temubual. Sesi temubual telah dirakam dan verbatim telah disediakan bagi tujuan analisis data bagi mencapai objektif-objektif kajian.

\section{Dapatan Kajian}

Dapatan kajian dibentangkan mengikut objektif-objektif yang cuba dicapai melalui kajian ini.

\subsection{Tahap KBAT Dalam Kalangan Pelajar}

Berdasarkan dapatan yang diperoleh daripada temubual, tahap KBAT dalam kalangan pelajar masih perlu diperkasakan. Dalam hal ini, informan menyatakan bahawa perbezaan tahap sosioekonomi pelajar menjadi faktor yang menyumbang kepada penguasaan KBAT dalam kalangan pelajar. Selain itu, informan turut menyatakan bahawa meskipun elemen KBAT, diterapkan di semua sekolah, tahap penerapan KBAT bergantung kepada jenis sekolah yang terdapat di Malaysia. Dapatan ini ditunjukkan melalui respon yang diberikan oleh guru seperti berikut:

"Pada pandangan saya, tahap pemikiran berfikir aras tinggi di Malaysia ini perlu lagi diperkasakan sebab tidak semua pelajar dapat menguasai dengan baik disebabkan kita memiliki tahap sosio ekonomi yang berbeza. Ada pelajar yang daripada kumpulan ibu bapa berpendapatan tinggi, jadi mereka mungkin telah didedahkan dengan pelbagai ilmu pengetahuan yang memiliki alat PAK tersendiri. Jika nak dibandingkan dengan pelajar yang daripada golongan B40 mereka mungkin ada masalah dari segi internet. Jadi sukar untuk mereka mencari maklumat baru..."

“...saya rasa semua sekolah di Malaysia sama ada di bandar di luar bandar sekolah harian ataupun Sekolah Berasrama Penuh tetap mengaplikasikan elemen KBAT. Cumanya elemen ini dapat disimulasikan secara menyeluruh ataupun tidak bergantung kepada keadaan pelajar. Sebagai contoh mungkin pelajar harian kita tidak boleh menggunakan soalan KBAT secara aras yang tinggi. Mungkin kepada Sekolah Berasrama Penuh kita boleh menggunakannya seratus-peratus KBAT. Sebabnya asrama penuh jika kita menggunakan soalan beraras rendah ianya sesuatu yang sangat mudah bagi mereka. Tapi ini bergantung kepada situasi pelajar dan kreativiti pelajar...."

\subsection{Faktor Yang Mempengaruhi Guru Dalam Memilih Strategi Pengajaran Bagi Memupuk KBAT Dalam Kalangan Pelajar}

Berdasarkan dapatan yang diperoleh daripada temubual, terdapat tiga faktor yang mempengaruhi guru dalam pemilihan strategi pengajaran bagi memupuk KBAT dalam kalangan pelajar. Faktor pertama melibatkan tahap penguasaan murid, di mana faktor tersebut mempengaruhi jenis soalan KBAT yang perlu disediakan oleh guru. Faktor kedua melibatkan alat bantu mengajar (ABM), di mana ABM yang digunakan perlu melibatkan penggunaan teknologi maklumat dan komunikasi (TMK). Faktor ketiga melibatkan keadaan bilik darjah, di mana menurut informan, keadaan bilik darjah perlulah memiliki ciri-ciri pembelajaran abad ke-21 bagi memupuk KBAT dalam kalangan pelajar. Dapatan ini ditunjukkan melalui respon yang diberikan oleh guru seperti berikut:

"Yang pertama sekali adalah sebagai seorang guru, kita mesti bijak melihat keadaan tahap penguasaan murid. Sama ada murid yang diajar itu ialah murid lemah sederhana ataupun cemerlang. Soalan yang dikemukakan dalam menilai elemen KBAT mestilah berdasarkan keadaan faktor pelajar terlebih dahulu dan soalan mestilah sesuai dgn mereka. Dan jika pelajar lemah, kita tidak boleh terus menggunakan soalan aras tinggi..."

"Yang kedua adalah alat ABM. ABM yang digunakan mestilah ABM yang bersesuaian. Sebab yang paling penting sekali, dalam melangkah ke alaf yang lebih baru dalam sistem pendidikan, ABM yg paling berkesan adalah penggunaan TMK, kita boleh 
Nurulhuda Md Hassan, Nur An Nisa Fithri Mohd Noor, Yamuna Thasarathan, Qarihatun Najah Zainudin, Nur Syaidatul Aisyah Zainuri, Nurul Raihana Najwa Mohamad Rizuaden, Nurfara Adilah Muhamad Fauzi, Nurfatihah Tumin, Nur Afina Syahida Mohamad Jefri.

Perspektif Guru Terhadap Kemahiran Berfikir Aras Tinggi dalam Kalangan Pelajar.

Journal of Humanities and Social Sciences, vol. 3, no. 2, pp. 50-56, August 2021. DOI: 10.36079/lamintang.jhass-0302.237

mengajar pelajar dengan menggunakan pelbagai medium untuk sesi pembentangan. TMK ini membolehkan pelajar menyertai pelbagai ilmu tambahan...”

"Keadaan bilik darjah juga mestilah dalam keadaan yang berkonsepkan pembelajaran abad ke 21. Penggunaan abad ke-21 ialah salah satu teknik pembelajaran yang menekankan dalam untuk menjayakan abad ke-21 ini untuk elemen penting. Yang pertama adalah KBAT, sebagai satu elemen penting untuk menjayakan pembelajaran abad ke 21. Yang keduanya adalah penggunaan peta I-think. Peta I-think ini mampu menarik perhatian murid untuk minat terhadap sesuatu pembelajaran yang telah dijalankan oleh guru sebab peta i-think ada berbagai-bagai kaedah dan diwarnakan dalam bentuk yang menarik dan mungkin boleh menarik perhatian golongan pelajar yang mungkin kurang cemerlang..."

\subsection{Langkah Untuk Meningkatkan KBAT Dalam Kalangan Pelajar}

Berdasarkan dapatan yang diperoleh daripada temubual, langkah digunakan bagi meningkatkan KBAT dalam kalangan pelajar ialah teknik menyoal. Secara spesifik, menurut guru tersebut, teknik menyoal yang digunakan perlulah disesuaikan dengan aras pelajar dan melibatkan soalan-soalan KBAT, soalan-soalan yang menggalakkan komunikasi, dan soalan yang menggunakan kata kunci yang mudah difahami oleh pelajar. Dapatan ini ditunjukkan melalui respon yang diberikan oleh guru seperti berikut:

“...langkah yang perlu diambil oleh seorang guru untuk membina kemahiran KBAT kemahiran berfikir aras tinggi dalam kelas yang pertama sekali adalah teknik penyoalan. Sebelum cikgu memulakan kelas, cikgu mesti memastikan teknik penyoalan adalah sesuai dengan aras pelajar...cikgu kena bijak menggunakan soalan beraras tinggi yang sesuai dengan tahap kemahiran pelajar yang pelajar ada...soalan digunakan mestilah soalan berfikiran aras tinggi yang melibatkan pelajar boleh menganalisis, menaakul dan akhirya dapat mencipta sesuatu yang baru dan teknik soalan yang digunakan tu biarlah soalan yang dapat mewujudkan komunikasi. Satu adalah komunikasi yang pertama adalah antara pelajar dengan guru, pelajar dengan pelajar dan pelajar dengan berbagai-bagai supaya pelajar dapat membuat keputusan. Dan cikgu seharusnya menggunakan soalan yang menggunakan kata kunci yang mudah difahami oleh pelajar seperti wajarkah, seandainya. Yang paling penting adalah pelajar dapat memahami kehendak soalan, dapat menganalisis seterusnya menaakul...”

\subsection{Strategi Untuk Menggalakkan Pelajar Mengaplikasikan KBAT Ketika Menghadapi Penilaian}

Berdasarkan dapatan yang diperoleh daripada temubual, terdapat tiga cara yang boleh digunakan oleh guru untuk menggalakkan pelajar mengaplikasi KBAT ketika menghadapi penilaian, iaitu dengan memberi soalan KBAT secara konsisten kepada pelajar, menggunakan kaedah pembelajaran abad ke21 yang melibatkan penggunaan teknologi maklumat dan komunikasi dan perbincangan kumpulan, serta pemberian tugasan untuk disiap dan dibentangkan secara berkumpulan. Dapatan ini ditunjukkan melalui respon yang diberikan oleh guru seperti berikut:

“...guru mestilah memberi soalan KBAT secara konsisten kepada pelajar. Maksudnya adaptasi dalam kelas masa waktu PdPc mestilah secara berterusan untuk memastikan pelajar di sekolah sudah biasa dengan keadaan dengan soalan KBAT..."

"TMK merupakan salah satu sistem pembelajaran abad ke -21 yang boleh membantu pelajar dalam mengasas kemahiran mereka dalam mencipta sesuatu yang baru. Yang keduanya adalah perbincangan dalam kumpulan iaitu melalui PAK pembelajaran abad ke-21 sangat penting di mana apabila berlakunya perbincangan dalam kumpulan, ideaidea pelajar akan bercambah. Mereka akan menjadi pelajar yang lebih berani, pelajar yang bersikap lebih terbuka..."

"Yang ketiganya ialah mungkin cikgu boleh memberikan lembaran kerja atau folio kepada pelajar dan mereka dikehendaki menyiapkan secara berkumpulan dan mengadakan sesi pembentangan. Selesai sesi pembentangan mungkin pelajar berkenaan 
Nurulhuda Md Hassan, Nur An Nisa Fithri Mohd Noor, Yamuna Thasarathan, Qarihatun Najah Zainudin, Nur Syaidatul Aisyah Zainuri, Nurul Raihana Najwa Mohamad Rizuaden, Nurfara Adilah Muhamad Fauzi, Nurfatihah Tumin, Nur Afina Syahida Mohamad Jefri.

Perspektif Guru Terhadap Kemahiran Berfikir Aras Tinggi dalam Kalangan Pelajar.

Journal of Humanities and Social Sciences, vol. 3, no. 2, pp. 50-56, August 2021. DOI: 10.36079/lamintang.jhass-0302.237

boleh mengajukan beberapa soalan. Di sini kita dapat melihat di mana pelajar lebih yakin, mereka lebih kreatif dan lebih inovatif dalam menyampaikan sesuatu tugasan..."

\subsection{Cabaran Guru untuk Memupuk KBAT Dalam Kalangan Pelajar}

Berdasarkan dapatan yang diperoleh daripada temubual, terdapat dua cabaran yang dihadapi oleh guru untuk memupuk KBAT dalam kalangan pelajar. Cabaran pertama yang dinyatakan oleh guru ialah kekangan masa, di mana kesibukan guru untuk menghabiskan sukatan pelajaran menyebabkan penerapan elemen KBAT kurang diberi perhatian. Selain itu, cabaran yang dihadapi oleh guru ialah dari segi faktor pelajar yang tidak aktif, di mana tahap pengetahuan pelajar sedikit sebanyak menjejaskan kelancaran penerapan elemen KBAT yang ingin dilaksanakan ketika sesi pengajaran dan pembelajaran berlangsung. Dapatan ini ditunjukkan melalui respon yang diberikan oleh guru seperti berikut:

“...mengikut pandangan saya okay yang pertama sekali, kekangan dari segi masa. Kebanyakan cikgu di sekolah adalah perlu menghabiskan silibus dalam masa yang telah ditetapkan. Jadi terutama sekali pada kelas peperiksaan seperti SPM dan STPM contohnya. Apabila setiap habis silibus, mereka dikehendaki melakukan latih tubi, jika kita membuat elemen KBAT ini secara berpusat, kemungkinan besar silibus tidak dapat dihabiskan mengikut waktu ditetapkan. Dan kekangan kedua, adalah pelajar tidak aktif. Tidak semua pelajar aktif. Puncanya adalah daripada pelajar yang mempunyai pengetahuan yang terhad. Cikgu mungkin akan memberi soalan KBAT, jika pelajar mempunyai pengetahuan yang agak terhad agak sukar mereka untuk berbincang dan membuat aktiviti kumpulan dan KBAT mungkin tidak dapat dilaksanakan secara efisien..."

\subsection{Kesan Sekiranya Pelajar Tidak Memiliki KBAT}

Berdasarkan dapatan yang diperoleh daripada temubual, informan menyatakan bahawa antara kesan yang bakal dihadapi sekiranya pelajar tidak memiliki KBAT ialah 1) kekurangan pelajar berminda kelas pertama dan mampu bersaing di peringkat global, 2) kegagalan untuk melahirkan pelajar yang berdaya tahan berdaya tahan, pemikir, fasih berkomunikasi, kerja secara berpasukan, bersifat ingin tahu, berprinsip, bermaklumat, prihatin dan mempunyai semangat patriotik, 3) kegagalan untuk melahiran golongan yang mempunyai kemahiran berfikir secara kritis dan kreatif, 4) kegagalan untuk melahirkan golongan yang memiliki ciri-ciri sebagai seorang pemimpin, serta 5) kegagalan untuk mencapai aspirasi murid seperti yang dinyatakan dalam Pelan Pembangunan Pendidikan Malaysia 2013-2025 [14]. Dapatan ini ditunjukkan melalui respon yang diberikan oleh guru seperti berikut:

“...sekiranya pelajar, tidak memiliki KBAT, negara kita mungkin akan mengalami masalah kurangnya pelajar yang berminda kelas pertama dan mampu bersaing di peringkat global..."

"Dan juga kita juga tidak akan dapat melahirkan pelajar yang berdaya tahan, pemikir, fasih berkomunikasi, kerja secara berpasukan, bersifat ingin tahu, berprinsip, bermaklumat, prihatin dan mempunyai semangat patriotik..."

“...impaknya sangat negatif terhadap negara sebab kita tidak dapat melahirkan golongan yang boleh berfikir secara kritis dan kreatif...”

“...sekolah mungkin kehilangan golongan pemimpin sebab di sekolah kita menerapkan nilai-nilai kepemimpinan dalam pelajar sama ada dalam persatuan kelab, ataupun kelas...Dan kita juga akan kehilangan pelajar yang boleh berkerja secara berkumpulan. Jika tiada pelajar yang boleh berkerja secara kumpulan, kita tidak dapat melahirkan golongan pemimpin sejak kecil lagi dan soalan KBAT ini sangat penting dalam pelajar supaya mereka lebih berfikiran terbuka dan berminda kelas pertama dan akhirnya mereka menjadi orang yang boleh berfikir di luar kotak dan selain mencapai keputusan cemerlang dalam peperiksaan awam...kita akan menimbulkan masalah yang tidak dapat melahirkan pemimpin yang mampu memajukan ekonomi sosial dan politik negara pada masa akan datang..."

"Jika mereka tidak memiliki kemahiran berfikir aras tinggi, kita tidak akan dapat mencapai aspirasi murid dalam PPPM 2013 hingga 2025 yang merangkumkan 6 elemen 
Nurulhuda Md Hassan, Nur An Nisa Fithri Mohd Noor, Yamuna Thasarathan, Qarihatun Najah Zainudin, Nur Syaidatul Aisyah Zainuri, Nurul Raihana Najwa Mohamad Rizuaden, Nurfara Adilah Muhamad Fauzi, Nurfatihah Tumin, Nur Afina Syahida Mohamad Jefri.

Perspektif Guru Terhadap Kemahiran Berfikir Aras Tinggi dalam Kalangan Pelajar.

Journal of Humanities and Social Sciences, vol. 3, no. 2, pp. 50-56, August 2021. DOI: 10.36079/lamintang.jhass-0302.237

penting iaitu pelajar kita tidak akan ada kemahiran berfikir maksudnya mereka tidak ada pengetahuan baru untuk menilai dan membuat keputusan. Pelajar kita juga tidak akan memiliki pengetahuan, pengetahuan maksudnya pelajar perlu memiliki semua ilmu pengetahuan sama ada Sains, Matematik dan bahasa. Kemudian pelajar juga tidak akan ada ciri-ciri kepemimpinan maksudnya kita tidak berjaya melahirkan golongan yang ada nilai-nilai kepimpinan sebab mereka tidak terbiasa dengan elemen KBAT iaitu kerja secara berpasukan. Seterusnya pelajar juga tidak akan ada kemahiran dwibahasa. Kemahiran dwibahasa ini pelajar di Malaysia ini diingatkan supaya mempunyai dua bahasa, Bahasa Melayu, Bahasa Inggeris dan elemen bahasa tambahan. Maksudnya pelajar tidak akan ada etika dan kerohanian. Dan seterusnya identiti nasional. Identiti nasional ini sama ada pelajar memiliki bangsa yang berbeza kita ada budaya yang berbeza tetapi kita mesti bangga menjadi rakyat Malaysia. Jadi pelajar tidak akan ada aspirasi ini jika elemen KBAT ini tidak diasimilasikan dalam diri pelajar sejak mereka sekolah lagi..."

\section{Perbincangan}

Dapatan kajian menunjukkan bahawa teknik menyoal merupakan teknik yang digunakan oleh guru untuk memupuk KBAT dalam kalangan pelajar. Hal ini adalah selari dengan dapatan kajian yang dijalankan oleh Sulaiman et. al. [8] yang mendapati bahawa teknik menyoal sebagai teknik terbaik yang digunakan oleh guru untuk memupuk KBAT dalam kalangan pelajar. Dapatan ini boleh dijustifikasi dengan mengambilkira kebolehan teknik menyoal dalam membina KBAT. Berdasarkan kajian yang dijalankan oleh Sulaiman et al. [8], teknik menyoal membolehkan guru mengajukan soalan-soalan aras tinggi berkaitan konsep yang diajar dan soalan-soalan berasaskan kehidupan sebenar. Dalam konteks pendidikan, penggunaan soalan yang bersifat autentik memainkan peranan penting bukan sahaja dalam membina KBAT, tetapi dalam menjadikan pembelajaran sebagai sesuatu yang bermakna melalui perkaitan antara konsep yang dipelajari dengan kehidupan sebenar pelajar.

Dapatan kajian turut menunjukkan bahawa terdapat pelbagai strategi yang boleh digunakan bagi meningkatkan KBAT dalam kalangan pelajar. Dapatan ini disokong oleh pendapat Ichsan et al. [6] yang menyatakan bahawa KBAT dalam kalangan pelajar boleh ditingkatkan melalui pelbagai medium dan bahan pembelajaran yang berasaskan KBAT. Secara spesifik, dapatan kajian menunjukkan bahawa pengintegrasian elemen PAK21 merupakan antara strategi yang boleh digunakan bagi memupuk KBAT dalam kalangan pelajar. Dapatan ini adalah selari dengan pandangan Fadzli Ali Karim dan Marzita Puteh [3] yang menyatakan keperluan guru untuk menerapkan kaedah-kaedah pengajaran yang telah digariskan dalam PAK21.

Dapatan ini boleh dijustifikasi dengan mengambilkira kepentingan penerapan elemen PAK21 dalam konteks pembelajaran pelajar. Sebagai contoh, penggunaan TMK dalam proses pengajaran dan pembelajaran mewujudkan suasana pembelajaran yang produktif kepada pelajar [1]. Berdasarkan dapatan kajian oleh Sulaiman et al. [8] pula, penggunaan peta I-Think didapati menggalakkan pelajar untuk terlibat dalam kemahiran menganalisis, manakala aktiviti pembelajaran dalam kumpulan seperti pembelajaran berasakan masalah dan pembelajaran berasaskan projek didapati menggalakkan pelajar untuk mengaplikasi kreativiti mereka.

Selain itu, dapatan kajian menunjukkan keperluan guru untuk menyediakan soalan-soalan KBAT yang bersesuaian dengan tahap kemahiran pelajar serta menggunakan kata kunci yang mudah difahami. Kesesuaian soalan dengan tahap kemahiran pelajar dan penggunaan kata kunci yang mudah difahami merupakan antara perkara penting yang perlu diberi perhatian bagi memastikan keberkesanan penerapan elemen KBAT dalam kalangan pelajar. Menurut Karim \& Puteh [3], proses pengajaran dan pembelajaran perlu dirancang dengan teliti agar kaedah terbaik dapat digunakan bagi memperkasa pelajar, terutama dalam menjawab soalan-soalan KBAT.

Hasil kajian mendapati bahawa kekangan masa memberikan cabaran kepada guru untuk menerapkan elemen KBAT dalam proses pengajaran dan pembelajaran. Dapatan kajian ini adalah selari dengan dapatan kajian lepas yang dijalankan oleh Othman \& Kassim [1] serta Ganapathy et al. [15]. Dalam hal ini, guru didapati mempunyai masa yang tidak mencukupi untuk merancang pengajaran yang benar-benar berkesan dalam menerapkan KBAT dalam kalangan pelajar [16]. Selain itu, kebanyakan guru mengalami kesukaran dalam melaksanakan strategi-strategi dan aktiviti-aktiviti yang melibatkan KBAT disebabkan kekangan masa meskipun para guru menyedari kepentingan KBAT dalam pembelajaran pelajar. 
Nurulhuda Md Hassan, Nur An Nisa Fithri Mohd Noor, Yamuna Thasarathan, Qarihatun Najah Zainudin, Nur Syaidatul Aisyah Zainuri, Nurul Raihana Najwa Mohamad Rizuaden, Nurfara Adilah Muhamad Fauzi, Nurfatihah Tumin, Nur Afina Syahida Mohamad Jefri.

Perspektif Guru Terhadap Kemahiran Berfikir Aras Tinggi dalam Kalangan Pelajar.

Journal of Humanities and Social Sciences, vol. 3, no. 2, pp. 50-56, August 2021. DOI: 10.36079/lamintang.jhass-0302.237

\section{Kesimpulan}

Sebagai kesimpulan, kajian ini memberi maklumat yang bermanfaat berkaitan dengan langkahlangkah yang boleh diambil bagi memupuk dan meningkatkan KBAT dalam kalangan pelajar. Secara ringkas, dapatan yang diperoleh melalui kajian ini menyarankan agar guru menggunakan teknik menyoal dan strategi-strategi pengajaran yang bersesuaian dengan PAK21 dalam usaha meningkatkan KBAT dalam kalangan pelajar. Selain itu, aspek psikologi pelajar juga perlu diberi perhatian bagi meningkatkan keberkesanan pendekatan, strategi, dan teknik yang digunakan dalam usaha meningkatkan KBAT dalam kalangan pelajar. Walaubagaimanapun, kajian ini terbatas kepada jumlah informan yang kecil. Kajian lanjutan dicadangkan agar melibatkan bilangan informan yang lebih ramai agar maklumat yang lebih komprehensif berkaitan dengan KBAT dapat diperoleh.

\section{Rujukan}

[1] M. S. Othman and A. Y. Kassim, "Isu dan permasalahan (PdP) pelaksanaan kemahiran berfikir aras tinggi (KBAT) dalam amalan pengajaran guru menurut pandangan Ibnu Khaldun," Journal of Human Capital Development, vol. 10, no. 1, 2017.

[2] Kementerian Pendidikan Malaysia, Kemahiran Berfikir Aras Tinggi (KBAT) Untuk Panduan Sekolah. Putrajaya, Malaysia: Kementerian Pendidikan Malaysia, 2013.

[3] F. A. Karim and M. Puteh, "The development of higher order thinking skills (HOTS) assessment instrument for word problems," International Journal of Academic Research in Business and Social Sciences, vol. 9, no. 6, pp. 1079-1083, 2019.

[4] L. Goodson and F. Rohani, "Higher order thinking skills: Definition, teaching strategies, assessment," Thinking, vol. 18, no. 458, 1998.

[5] N. Othman and K. A. Mohamad, "Thinking skill education and transformational progress in Malaysia," International Education Studies, vol. 7, no. 4, 2014.

[6] I. Z Ichsan, D. V. Sigit, M. Miarsyah, A. Ali, W. P. Arif and T. A. Prayitno, "HOTS-AEP: Higher order thinking skills from elementary to master students in environmental learning," European Journal of Educational Research, vol. 8, no. 4, pp. 935-942, 2019.

[7] M. H. M. Hisham, M. S. Saud and Y.i Kamin, "Meta-analysis study of teacher issues on higher order thinking skills in Malaysia," World Applied Sciences Journal, vol. 35, no. 12, pp. 2520 $2523,2017$.

[8] T. N. Sulaiman, V. Muniyan, D. Madhvan, R. Hasan and S. S. A. Rahim, International Research Journal of Education and Sciences (IRJES), vol. 1, no. 1, pp. 1-3, 2017.

[9] F. Othman and S. Rahman, Kepentingan penyebatian kemahiran berfikir secara kritis dan kreatif $(K B K K)$ dalam proses pengajaran dan pembelajaran. Pembentangan Seminar Serantau ke 5/2011. Indonesia: Riau, 2011.

[10] A. Chalkiadaki, "A systematic literature review of 21 st century skills and competencies in primary education," International Journal of Instruction, vol. 11, no. 3, pp. 1-16, 2018.

[11] A. C. Saputri, S. Sajidan, Y. Rinanto, A. Afandi, and N. M. Prasetyanti, "Improving students' critical thinking skills in cell-metabolism learning using stimulating higher order thinking skills model," International Journal of Instruction, vol. 12, no. 1, pp. 327-342, 2018.

[12] N. H. H. Abdullah and G. Darusalam, "Kesediaan guru melaksanankan kemahiran berfikir aras tinggi dalam pengajaran," Jurnal Kurikulum \& Pengajaran Asia Pasifik, vol. 6, no. 2, pp. 1-10, 2018.

[13] N. Kamarudin, "Kemahiran guru sebagai pengurus dalam meningkatkan penglibatan pelajar dalam kerja amali Fizik," Jurnal Pemikir Pendidikan, vol. 3, no. 3, pp. 141-157, 2013.

[14] Kementerian Pendidikan Malaysia, Pelan Pembangunan Pendidikan Malaysia 2013-2025 (Prasekolah hingga Lepas Menengah). Putrajaya, Malaysia: Kementerian Pendidikan Malaysia, 2013.

[15] M. Ganapathy, M. K. M Singh, S. Kaur and W. K. Liew, "Promoting higher order thinking skills via teaching practices," 3L: The Southeast Asian Journal of English Language Studies, vol. 23, no. 1, pp. $75-85,2017$.

[16] N. Sener, C. Turk and E. Tas, "Improving science attitude and creative thinking through science education project: A design, implementation and assessment," Journal of Education and Training Studies, vol. 3, no. 4, pp. 57 - 67, 2015. 